\title{
GMR
}

Corrigendum

\section{Corrigendum: Correlation between adiponectin (ADPN) and hemorrhagic shock in mice - Genet. Mol. Res. 15 (1): gmr.15017037 (DOI: 10.4238/gmr.15017037)}

Corrected after publication: June 29, 2017

DOI: http://dx.doi.org/10.4238/gmr160270371

Copyright $(2017$ The Authors. This is an open-access article distributed under the terms of the Creative Commons Attribution ShareAlike (CC BY-SA) 4.0 License.

Gong X, Liu Y, Yao S, Zheng JF, et al. (2016). Correlation between adiponectin (ADPN) and hemorrhagic shock in mice. Genet. Mol. Res. 15: gmr.15017037.

Due to signature dispute, the new author's list and corresponding author from the article above, published on February 5, 2016, are:

X. Gong, Y. Liu, S. Yao and J.F. Zheng

Corresponding author: X. Gong

E-mail: gongxun1246@163.com 